Check for updates

Cite this: RSC Adv., 2017, 7, 24822

Received 11th February 2017

Accepted 3rd May 2017

DOI: $10.1039 / c 7 r a 01731 f$

rsc.li/rsc-advances

\title{
A novel long-wavelength fluorescent probe for discrimination of different palladium species based on Pd-catalyzed reactions $\uparrow$
}

\author{
Ting Yu, Guoxing Yin, Peng Yin, (D) * Ying Zeng, Haitao Li, (D)* Youyu Zhang \\ and Shouzhuo Yao
}

\begin{abstract}
We have synthesized a novel long-wavelength fluorescent probe MFC for detection of palladium $\left(\mathrm{Pd}^{0}\right)$. This probe not only shows high selectivity for palladium, but also could quickly discriminate different palladium species $\left(\mathrm{Pd}^{0}, \mathrm{Pd}^{2+}, \mathrm{Pd}^{4+}\right)$ in phosphate buffered solution. After the reaction with $\mathrm{Pd}\left(\mathrm{PPh}_{3}\right)_{4}$, the UV absorption of the probe MFC shifts from $334 \mathrm{~nm}$ to $594 \mathrm{~nm}$ within a few minutes. The probe MFC conjugated with alkyl carbamate, which destroys the principle of intramolecular charge transfer (ICT) and shows weak fluorescence. Based on the $\mathrm{Pd}^{0}$-catalyzed Tsuji-Trost deallylation reaction, the fluorogen was released and the fluorescence intensity at $612 \mathrm{~nm}$ was observed with 13-fold enhancement along with an obvious color change from yellow to purple with low detection limit.
\end{abstract}

\section{Introduction}

Palladium, one of the most important noble transitional metal catalysts, is widely used in organic reactions, medical instruments, fuel crowns, electronics and jewellery. ${ }^{1-5}$ The concern of palladium for human health and environmental contamination is increasing and a lot of attention has been paid to it recently. ${ }^{6}$ In particular, palladium could bind to thiol-containing proteins, DNA, and other biomolecules, causing potential toxicity and carcinogenicity to humans, and it is strongly limited by governmental regulations to 5-10 ppm in end products. ${ }^{7-10}$ Therefore, it is urgently required to develop methods for selective and sensitive monitoring of palladium species in the environment, food and living organisms.

The traditional analytical methods for detecting palladium species are atomic absorption spectroscopy (AAS), inductively coupled plasma mass spectrometry (ICP-MS), inductively coupled plasma optical emission spectrometry (ICP-OES), solid phase micro extraction-high performance liquid chromatography and X-ray fluorescence, which require expensive instruments and well-trained individuals. ${ }^{\text {11-14 }}$ Recently, fluorescent probes have been widely applied in biological and environmental studies owing to its simple operation, low-cost, high sensitivity and high selectivity. ${ }^{\mathbf{1 5 - 1 9}}$ Plenty of fluorescent probes

Key Laboratory of Chemical Biology and Traditional Chinese Medicine Research, Ministry of Education, College of Chemistry and Chemical Engineering, Hunan Normal University, Changsha 410081, PR China. E-mail: yinpeng@hunnu.edu.cn; haitaoli@hunnu.edu.cn

$\dagger$ Electronic supplementary information (ESI) available: Structural characterization data, absorption and fluorescence spectra, TLC, ${ }^{1} \mathrm{H} \mathrm{NMR},{ }^{13} \mathrm{C}$ NMR, and HRMS. See DOI: 10.1039/c7ra01731f have been reported for the detection of palladium, most of which were based on the $\mathrm{Pd}^{0}$-catalyzed Tsuji-Trost deallylation and depropargylation. ${ }^{20-24}$ Consequently, several fluorescence probes based on intramolecular charge transfer (ICT) and the excited stated intramolecular proton transfer (ESIPT) had been reported. $\mathrm{Liu}^{24}$ et al. designed a novel turn-on ratiometric fluorescence probe by ICT, which conducted two-photon fluorescent platform with a rigid oxygen-bridge conformation based on the green fluorescence protein. Zhang ${ }^{25}$ et al. designed a coumarin-based fluorescent probe for the detection of palladium with the detection limit to be $0.34 \mathrm{nM}$. Also, this probe showed nonfluorescence when connecting with allky carbonate ester. Wang ${ }^{26}$ et al. synthesized a colorimetric and turn-on fluorescent probe for the detection of palladium with high selectivity and sensitivity, which also used the allyl carbamate as the recognition unit for palladium likewise others. However, some of them still have some limitations including long time reaction times, emission in the short-wavelength region and small Stroke shift, which limits their applications in vivo. Therefore, developing some palladium fluorescent probe that could emit in the red or NIR region is of great importance, for the longer wavelength fluorescence could reduce the background interference from the indigenous biomolecules of the living organisms.

2-Dicyano-methylene-3-cyano-4,5,5-trimethyl-2,5-dihydrofuran (TCF) and its derivatives have typical donor- $\pi$-acceptor (D- $\pi-\mathrm{A})$ structure, longer emission wavelength in the red (or NIR) region, which contribute their application in dye-sensitized solar cells, bio-imaging and organic nonlinear optical crystals..$^{27-35}$ Herein, a long-wavelength fluorescent probe (MFC) was designed for sensing palladium species, based on the properties of TCF and the principle of intramolecular charge transfer (ICT) (Scheme 1). ${ }^{36}$ 


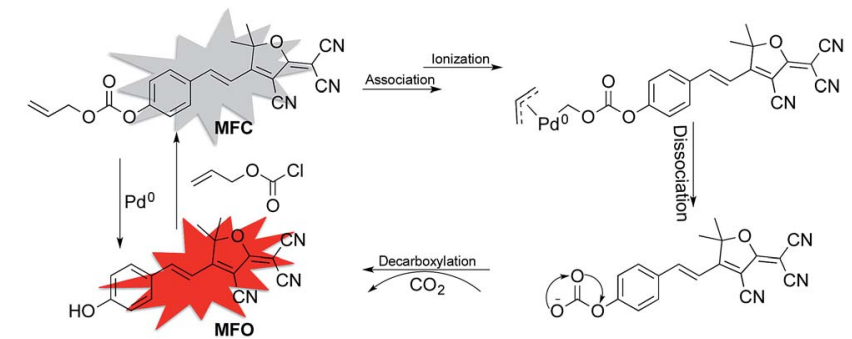

Scheme 1 Structure of probe MFC and the proposed mechanism for selective recognition of $\mathrm{Pd}^{0}$.

Allyl carbamate group was usually used as the response unit for $\mathrm{Pd}^{0}$. After reaction with palladium, the ally carbamate group would be cleaved from the probe, and substrate with strong fluorescence would be released. The probe MFC showed high sensitivity and selectivity toward palladium and met the requirement of both emitting in the red wavelength region and naked eye detection.

\section{Experimental}

\section{Materials and instrumentation}

The chemicals and solvents were purchased from Aladdin (Shanghai, China) and used without further purification. $\mathrm{Pd}\left(\mathrm{PPh}_{3}\right)_{4}, \mathrm{NaCl}, \mathrm{KCl}, \mathrm{AgNO}_{3}, \mathrm{ZnCl}_{2}, \mathrm{CdCl}_{2}, \mathrm{FeCl}_{3}, \mathrm{CrCl}_{3}, \mathrm{CuCl}_{2}$, $\mathrm{Hg}\left(\mathrm{NO}_{3}\right)_{2}, \mathrm{MnCl}_{2}, \mathrm{PbCl}_{2}, \mathrm{Na}_{2} \mathrm{HPO}_{4}, \mathrm{NaH}_{2} \mathrm{PO}_{4}, \mathrm{Pd}\left(\mathrm{PPh}_{3}\right)_{2} \mathrm{Cl}_{2}$, $\left(\mathrm{NH}_{4}\right)_{2} \mathrm{PdCl}_{6},\left(\mathrm{MeCN}_{2} \mathrm{PdCl}_{2}, \mathrm{NaBH}_{4}\right.$ were of analytical grade. TLC analysis was performed using precoated silica plates. UVvis absorption spectra were collected on a UV-2450 spectrophotometer (Shimadzu Co., Japan). Fluorescence spectra were recorded on Hitachi F-7000 spectrophotometer (Hitachi Ltd, Japan). ${ }^{1} \mathrm{H}$ NMR and ${ }^{13} \mathrm{C}$ NMR spectra were obtained with tetramethyl silane (TMS) as the internal standard on a BRUKER AVANCE-500 spectrometer. IR spectrum was recorded on NEXUS as $\mathrm{KBr}$ pellets and were reported in $\mathrm{cm}^{-1}$. HRMS spectrum was recorded on AB TripleTOF 5600+ (U.S AB SCIEX).

\section{Synthesis of compound TCF}

Compound TCF was prepared according to the literature method. ${ }^{37}$ To a mixture of 3-hydroxy-3-methylbutan-2-one (9.00 g, $88.12 \mathrm{mmol})$, malononitrile $(11.92 \mathrm{~g}, 180.43 \mathrm{mmol})$ in ethanol $(30 \mathrm{~mL})$ was added sodium ethanol $(0.90 \mathrm{~g}, 13.22$ $\mathrm{mmol}$ ), then the mixture was heated to reflux for $2 \mathrm{~h}$ until no starting compound was indicated by thin layer chromatography (TLC). After cooled to room temperature, the mixture was filtered and washed with cooled ethanol three times. The residue was dried under vacuum to give $15.00 \mathrm{~g}(85.71 \%)$ of TCF as gray solid. ${ }^{1} \mathrm{H}$ NMR (500 MHz, chloroform- $d$ ) $\delta: 2.39(\mathrm{~s}, 3 \mathrm{H})$, 1.65 (s, 6H). ${ }^{13} \mathrm{C}$ NMR (126 MHz, chloroform- $d$ ) $\delta: 182.7,175.2$, 111.0, 109.0, 104.8, 99.8, 58.4, 24.4, 14.2.

\section{Synthesis of MFO}

A mixture of TCF $(0.60 \mathrm{~g}, 3.01 \mathrm{mmol})$ and 4-hydroxybenzaldehyde $(0.38 \mathrm{~g}, 3.10 \mathrm{mmol})$ in ethanol $(20 \mathrm{~mL})$ was heated to reflux until compound TCF had been consumed, which was monitored by TLC. After cooled to room temperature, the mixture was filtered and washed with cooled ethanol three times. The residue was dried under vacuum to give $0.80 \mathrm{~g}(88.88 \%)$ pure product of MFO as red solid. ${ }^{1} \mathrm{H}$ NMR (500 MHz, DMSO- $\left.d_{6}\right) \delta: 10.62(\mathrm{~s}, 1 \mathrm{H}), 7.91$ $(\mathrm{d}, J=16.1 \mathrm{~Hz}, 1 \mathrm{H}), 7.81(\mathrm{~d}, J=8.3 \mathrm{~Hz}, 2 \mathrm{H}), 7.02(\mathrm{~d}, J=16.2 \mathrm{~Hz}$, $1 \mathrm{H}), 6.91$ (d, $J=8.3 \mathrm{~Hz}, 2 \mathrm{H}), 1.78(\mathrm{~s}, 6 \mathrm{H}) .{ }^{13} \mathrm{C} \mathrm{NMR}(126 \mathrm{MHz}$, DMSO- $\left.d_{6}\right) \delta 177.7,176.3,162.8,148.8,132.8,126.2,116.9,113.4$, 112.6, 112.2, 111.7, 99.5, 97.0, 53.7, 25.8 ppm.

\section{Synthesis of probe MFC}

Compound MFO (0.60 g, $1.98 \mathrm{mmol})$ was dissolved in anhydrous acetonitrile and cooled to $0{ }^{\circ} \mathrm{C}$ by ice-water bath. Then allyl chloroformate $(0.24 \mathrm{~mL}, 2.19 \mathrm{mmol})$ and a few drops of redistilled triethylamine were added to the solution under stirring. The reaction mixture was stirred for $1 \mathrm{~h}$ and warmed to room temperature. After quenched by adding $10 \mathrm{~mL}$ water, the mixture was extracted with dichloromethane for three times. The combined organic layers ware dried over anhydrous $\mathrm{Na}_{2} \mathrm{SO}_{4}$. The solvent was filtered, and dried under vacuum to yield the brown solid (704 mg, 91.87\%). ${ }^{1} \mathrm{H}$ NMR (500 MHz, chloroform- $d$ ) $\delta 7.76-$ $7.69(\mathrm{~m}, 2 \mathrm{H}), 7.67$ (d, $J=16.4 \mathrm{~Hz}, 1 \mathrm{H}), 7.41-7.34(\mathrm{~m}, 2 \mathrm{H}), 7.02$ (d, $J$ $=16.4 \mathrm{~Hz}, 1 \mathrm{H}), 6.03(\mathrm{ddt}, J=16.5,10.4,5.9 \mathrm{~Hz}, 1 \mathrm{H}), 5.48(\mathrm{dq}, J=$ $17.2,1.4 \mathrm{~Hz}, 1 \mathrm{H}), 5.39$ (dd, $J=10.4,1.3 \mathrm{~Hz}, 1 \mathrm{H}), 4.79$ (dt, $J=5.9$, $1.4 \mathrm{~Hz}, 2 \mathrm{H}), 1.83(\mathrm{~s}, 6 \mathrm{H}) .{ }^{13} \mathrm{C}$ NMR (126 MHz, chloroform- $d$ ) $\delta 173.5,154.1,152.6,145.9,131.6,130.8,130.3,122.2,120.0$, $115.1,111.5,110.7,110.1,100.4,97.8,69.6,26.4$ ppm. IR $\left(\mathrm{cm}^{-1}\right)$ 3070, 3046, 2994, 2965, 2748, 2417, 2177, 1765, 1580, 1621, 1378, 1309, 950, 858, 774. HRMS (FTMS ESI ${ }^{+}$): $m / z$ calcd for $\mathrm{C}_{22} \mathrm{H}_{17} \mathrm{~N}_{3} \mathrm{O}_{4}$ $386.1141[\mathrm{M}-\mathrm{H}]^{-}$; found 386.1122 .

\section{General procedure for fluorescence and UV-visible measurements}

UV-vis absorption and fluorescence spectra studies were conducted in a mixture solution of DMSO/PBS $(10 \mathrm{mM}, \mathrm{pH}=7.4$, $3: 7, \mathrm{v} / \mathrm{v})$. A volume of $2.0 \mathrm{~mL}$ of the solution containing probe MFC (25 $\mu \mathrm{M}$ for UV-vis absorption and $10 \mu \mathrm{M}$ for fluorescence experiments) was first introduced to a quartz cell, following additions of $10 \mu \mathrm{L}$ of $\mathrm{Pd}\left(\mathrm{PPh}_{3}\right)_{4}$ stock solution $(10 \mathrm{mM})$. The kinetic investigations were carried out by measuring fluorescence intensities of the resulting mixture at different time intervals. The fluorescence intensities were recorded with an excitation wavelength of $560 \mathrm{~nm}$ and emission wavelength ranging from $580 \mathrm{~nm}$ to $700 \mathrm{~nm}$. Both the excitation and emission slit was set as $5.0 \mathrm{~nm}$. The responses of interferences were performed by adding 4 equiv. of different anions and palladium-containing compounds $(20 \mu \mathrm{M})$ to each sample. PBS buffers with different $\mathrm{pH}$ values were chosen for investigation the effect of $\mathrm{pH}$. The limit of detection (LOD) was determined by adding $\mathrm{Pd}\left(\mathrm{PPh}_{3}\right)_{4}$ over a series of concentrations into the probe MFC samples.

\section{Results and discussion}

\section{Probe design and synthesis}

The probe MFC was prepared conveniently according to the synthetic routine in Scheme 2. Firstly, the compound TCF was 


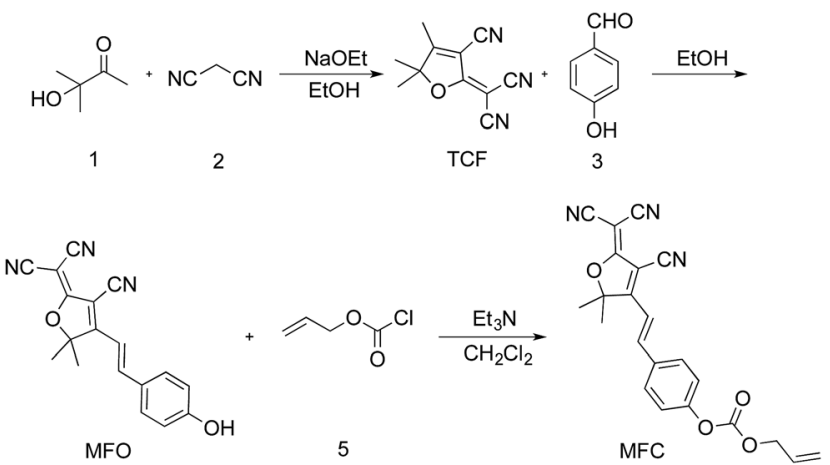

Scheme 2 Preparation of probe MFC.

prepared by the 3-hydroxy-3-methylbutan-2-one and malononitrile in ethanol and sodium ethanol. Next, the compound TCF and 4-hydroxybenzaldehyde was heated to reflux in ethanol, yielding the product MFO. Finally, the probe MFC was synthesized from MFO and allyl chloroformate with a satisfactory yield. The detailed characterizations of the intermediates and probe MFC are shown in the ESI (Fig. S5-S11 in ESI $\dagger$ ).

\section{The optical property and sensing potential of MFC}

The spectral properties of probe MFC were initially investigated in the absence and presence of $\mathrm{Pd}^{0}$ in a mixture solution of DMSO and PBS ( $\mathrm{pH}=7.4, \mathrm{v} / \mathrm{v} 3: 7) . \mathrm{Pd}\left(\mathrm{PPh}_{3}\right)_{4}$ was used as the resource of $\mathrm{Pd}^{0}$ in all of the experiments. The free probe MFC exhibits a major UV absorption at $334 \mathrm{~nm}$ as shown in Fig. 1a. However, after treated with 2.0 equiv. of $\mathrm{Pd}\left(\mathrm{PPh}_{3}\right)_{4}$, a remarkable change in the absorption spectrum was obtained and a high absorption peak was observed at $594 \mathrm{~nm}$ (Fig. 1a). Meanwhile, marked color changes of the solution were obviously noticed from yellow to purple in visible light, which could enable the naked-eye visual detection of $\mathrm{Pd}^{0}$ (inset Fig. 1a). Consistently, in the fluorescence spectra, probe MFC exhibited very weak fluorescence at $612 \mathrm{~nm}$ as expected when excited at $560 \mathrm{~nm}$, and a dramatic turn-on fluorescence enhancement at $612 \mathrm{~nm}$ was observed after triggered with $\mathrm{Pd}\left(\mathrm{PPh}_{3}\right)_{4}$ (Fig. 1b). Correspondingly, a notable colour change from bright blue to green was observed by naked eye when excited at $365 \mathrm{~nm}$ by handheld UV lamp (Fig. 1b inset).
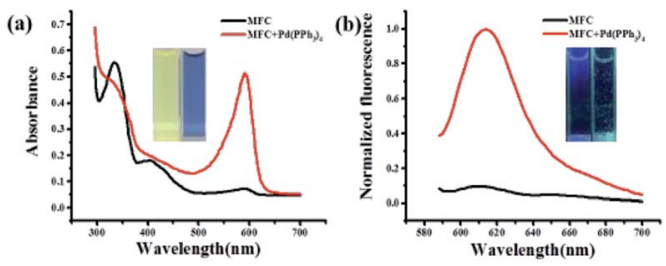

Fig. 1 (a) The absorption spectra and (b) the fluorescence spectra of probe MFC $(25 \mu \mathrm{M})$ and probe MFC with 2 equiv. of $\mathrm{Pd}\left(\mathrm{PPh}_{3}\right)_{4}$ at $37^{\circ} \mathrm{C}$ in DMSO/PBS buffer (10 mM, pH $=7.4,3: 7, \mathrm{v} / \mathrm{v}) . \lambda_{\mathrm{Ex}}=560 \mathrm{~nm}, \lambda_{\mathrm{Em}}=$ $612 \mathrm{~nm}$. Inset image: (a), left: visible-light of $10 \mu \mathrm{M}$ probe, right: $10 \mu \mathrm{M}$ probe with $20 \mu \mathrm{M} \mathrm{Pd}\left(\mathrm{PPh}_{3}\right)_{4}$; (b), left: fluorescence image of $10 \mu \mathrm{M}$ probe, right: $10 \mu \mathrm{M}$ probe with $20 \mu \mathrm{M} \mathrm{Pd}\left(\mathrm{PPh}_{3}\right)_{4}$.
The effect of the ratio of DMSO : PBS $(\mathrm{pH}=7.4)$ was also investigated (Fig. S1 in ESI $\dagger$ ). And the best ratio of DMSO/PBS ( $\mathrm{pH}=7.4$ ) was found to be $3: 7$. Furthermore, normally used buffer solutions (PBS, HEPES and Tris-HCl) were also tested for the probe MFC and the mixture of probe MFC with $\operatorname{Pd}\left(\mathrm{PPh}_{3}\right)_{4}$. Judging from the results, the buffer solution of PBS exhibited the best results (Fig. S2 in ESI†). Therefore, the following experiments were carried out in the solution of DMSO/PBS $(3: 7, \mathrm{v} / \mathrm{v})$. Encouraged by these observations, the timedependent fluorescence intensity changes of probe MFC in presence of $\mathrm{Pd}\left(\mathrm{PPh}_{3}\right)_{4}$ was studied (Fig. S3 in ESI $\left.\uparrow\right)$. Firstly, the stability experiments of the probe MFC at $\mathrm{pH} 7.4$ was investigated. Encouragingly, the probe MFC has little hydrolysis under pH 7.4 for $1 \mathrm{~h}$ (Fig. S3a in ESI $\dagger$ ). While, upon addition of 2.0 equiv. of $\operatorname{Pd}\left(\mathrm{PPh}_{3}\right)_{4}$ to the probe solution, an initial fast, followed by gradual increasement of the fluorescent intensity was obviously observed, and it came to a plateau in about $20 \mathrm{~min}$. Furthermore, the reaction of the probe MFC and $\mathrm{Pd}^{0}$ could be easily detected by TLC plate and most of the probe had been consumed after reacted with $\mathrm{Pd}\left(\mathrm{PPh}_{3}\right)_{4}$ for 20 min (Fig. S4 in ESI†).

\section{Effect of $\mathbf{p H}$}

With respect to the $\mathrm{pH}$ effect, as is well known, the carbonate group is sensitive to $\mathrm{pH}$ change and easily hydrolyzed under both acidic and basic media conditions. We examined the $\mathrm{pH}$ effect on probe MFC in the absence and presence of $\operatorname{Pd}\left(\mathrm{PPh}_{3}\right)_{4}$, respectively (Fig. 2). The probe was stable in a $\mathrm{pH}$ range of 2.06.0 monitored at $612 \mathrm{~nm}$. Fluorescence intensity changed little when $\mathrm{pH}$ value range 6.0-7.5. Once the probe was incubated with $\mathrm{Pd}\left(\mathrm{PPh}_{3}\right)_{4}$ within the $\mathrm{pH}$ value range 7.0-10.0, fluorescence intensity changed distinctly. These results indicated the response of probe MFC to $\mathrm{Pd}^{0}$ were favorable at $\mathrm{pH}$ range from 7.0-8.0 including the physiological conditions and the probe could be available for $\mathrm{Pd}^{0}$ detection in living organism.

\section{The sensitivity of probe MFC for palladium}

The capability of probe MFC for recognizing $\mathrm{Pd}^{0}$ was investigated by monitoring fluorescent intensities after adding different concentrations of $\mathrm{Pd}\left(\mathrm{PPh}_{3}\right)_{4}$ under the optimal conditions. The fluorescence intensities at $612 \mathrm{~nm}$ increased gradually with the

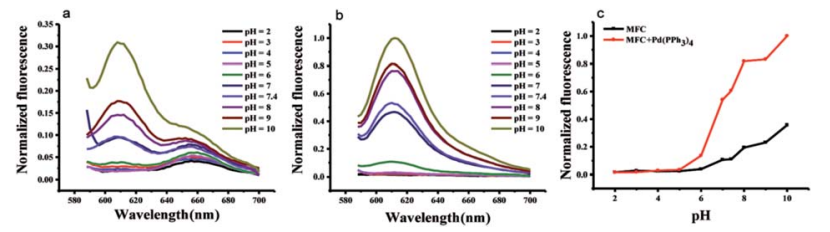

Fig. 2 (a) $\mathrm{pH}$-dependent normalized fluorescence intensity spectrum of free probe MFC $(10 \mu \mathrm{M})$ in DMSO-PBS buffer $(10 \mathrm{mM})$. (b) $\mathrm{pH}$ dependent normalized fluorescence intensity spectrum of probe MFC $(10 \mu \mathrm{M})$ with $\mathrm{Pd}\left(\mathrm{PPh}_{3}\right)_{4}(20 \mu \mathrm{M})$ in DMSO-PBS buffer $(10 \mathrm{mM}) . \lambda_{\mathrm{Ex}}=$ $560 \mathrm{~nm}, \lambda_{\mathrm{Em}}=612 \mathrm{~nm}$. (c) $\mathrm{pH}$ effect on the normalized fluorescence intensity spectrum of free probe MFC $(10 \mu \mathrm{M}$, black line) and probe MFC $(10 \mu \mathrm{M})$ with $\mathrm{Pd}\left(\mathrm{PPh}_{3}\right)_{4}(20 \mu \mathrm{M}$, red line) in DMSO-PBS buffer (10 $\mathrm{mM}) . \lambda_{\mathrm{Ex}}=560 \mathrm{~nm}, \lambda_{\mathrm{Em}}=612 \mathrm{~nm}$. 
increase of the concentration of $\mathrm{Pd}\left(\mathrm{PPh}_{3}\right)_{4}$ (Fig. 3). A good linearity of the fluorescence intensity at $612 \mathrm{~nm}$ versus the concentration of $\mathrm{Pd}\left(\mathrm{PPh}_{3}\right)_{4}$ from 0 to $2.0 \mu \mathrm{M}$ was obtained with the detection limit as $1.4 \mathrm{nM}\left(R^{2}=0.99356\right)$. And only 0.2 equiv. $\mathrm{Pd}^{0}$ could consume most of the probe MFC after $20 \mathrm{~min}$. Owing to the specific properties of palladium, probe MFC displayed a high sensitivity toward $\mathrm{Pd}^{0}$. The results indicated that a free product MFO was generated by the palladium-triggered reaction, which could indirectly be conformed by thin layer chromatography (TLC) (Fig. S4 in ESI $\dagger$ ).

\section{The selectivity of probe MFC for palladium}

To illustrate the good selectivity of this novel probe to $\mathrm{Pd}^{0}$, a series of metal ions were evaluated. As shown in Fig. 4a, only the addition of $\mathrm{Pd}^{0}$ induced remarkable fluorescence increase. In contrast, nearly no or little fluorescence changes were observed in the presence of $\mathrm{Fe}^{3+}, \mathrm{Mg}^{2+}, \mathrm{Cd}^{2+}, \mathrm{Co}^{2+}, \mathrm{Ba}^{2+}, \mathrm{Ni}^{+}$, $\mathrm{Cu}^{2+}, \mathrm{Ag}^{+}, \mathrm{Al}^{3+}, \mathrm{Ca}^{2+}, \mathrm{Li}^{+}, \mathrm{Zn}^{2+}, \mathrm{Mn}^{2+}, \mathrm{Hg}^{2+}$ and $\mathrm{Ti}^{3+}$. Competitive experiments involving the impacts of above mentioned metal ions in the detection of $\mathrm{Pd}^{0}$ were performed, which indicated the addition of various metal ions had a negligible effect on the $\mathrm{Pd}^{0}$ detection (Fig. 4b). These results demonstrated that the probe MFC showed an excellent selectivity to $\mathrm{Pd}^{0}$ over other competitive metal ions, which should be attributed to the specific $\mathrm{Pd}^{0}$-triggered reactions.

\section{The selectivity of probe MFC for different palladium}

The reactivities of probe MFC towards other oxidation states of palladium metal sources, such as $\mathrm{PbCl}_{2},(\mathrm{MeCN})_{2} \mathrm{PdCl}_{2}$, $\mathrm{Pd}\left(\mathrm{PPh}_{3}\right)_{2} \mathrm{Cl}_{2},\left(\mathrm{NH}_{4}\right)_{2} \mathrm{PdCl}_{6}$, were also examined. The addition of $\mathrm{Pd}^{2+}$ and $\mathrm{Pd}^{4+}$ to the solution of probe $\mathbf{M F C}$ had little fluorescence change even with long times (Fig. 4c). While, after the addition of micromolar $\mathrm{NaBH}_{4}$, similar responses to probe MFC as $\mathrm{Pd}^{0}$ were obtained, which meant that $\mathrm{Pd}^{2+} / \mathrm{Pd}^{4+}$ species could be reduced to $\mathrm{Pd}^{0}$ (Fig. $4 \mathrm{~d}$ ). That meant probe MFC could recognize the palladium species in all of the typical oxidation states and discriminate $\mathrm{Pd}^{0}$ from $\mathrm{Pd}^{2+} / \mathrm{Pd}^{4+}$ under different test conditions. These results demonstrated that probe MFC could be employed for specific recognition of $\mathrm{Pd}^{0}$ species.

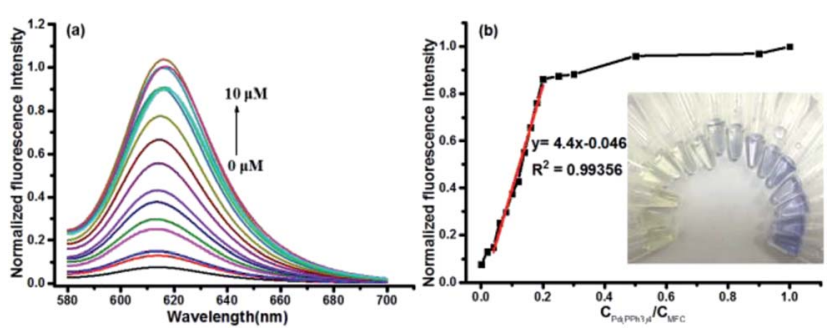

Fig. 3 (a) Normalized fluorescence intensity spectra of probe MFC (10 $\mu \mathrm{M})$ upon addition of increasing concentrations of $\mathrm{Pd}\left(\mathrm{PPh}_{3}\right)_{4}(0-10$ $\mu \mathrm{M})$ in DMSO-PBS buffer (10 mM, pH 7.4, $3: 7, \mathrm{v} / \mathrm{v}) . \lambda_{\mathrm{Ex}}=560 \mathrm{~nm}, \lambda_{\mathrm{Em}}$ $=612 \mathrm{~nm}$. (b) The linear relationship between the fluorescence intensity of probe MFC $(10 \mu \mathrm{M})$ at $612 \mathrm{~nm}$ and the concentrations of $\mathrm{Pd}\left(\mathrm{PPh}_{3}\right)_{4}(0-10 \mu \mathrm{M})$ in DMSO-PBS buffer $(10 \mathrm{mM}, \mathrm{pH} 7.4,3: 7, \mathrm{v} / \mathrm{v})$.
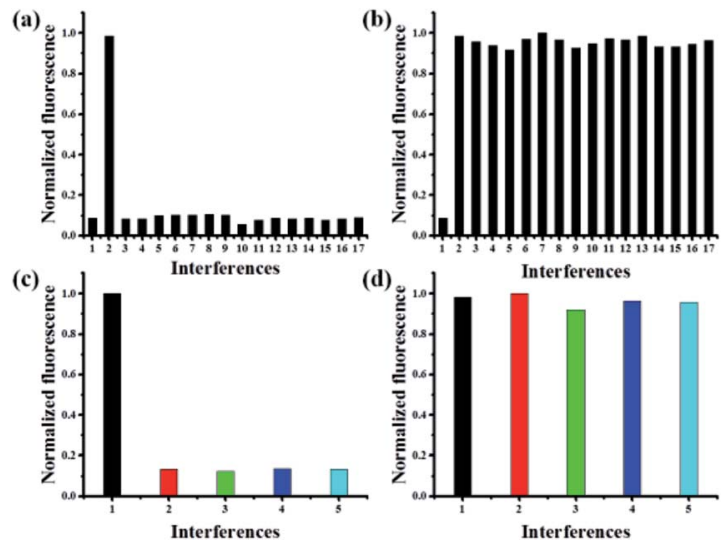

Fig. 4 (a) Normalized fluorescence intensity of probe MFC $(10 \mu \mathrm{M})$ and (b) probe MFC $(10 \mu \mathrm{M})$ with $\mathrm{Pd}\left(\mathrm{PPh}_{3}\right)_{4}(20 \mu \mathrm{M})$ in the presence of $40 \mu \mathrm{M}$ of different interferences in DMSO-PBS buffer $(10 \mathrm{mM}, \mathrm{pH}=$ 7.4): (1) blank, (2) $\mathrm{Pd}\left(\mathrm{PPh}_{3}\right)_{4}$, (3) $\mathrm{FeCl}_{3}$, (4) $\mathrm{MgCl}_{2}$, (5) $\mathrm{CdCl}_{2}$, (6) $\mathrm{CoCl}_{2}$, (7) $\mathrm{BaCl}_{2}$, (8) $\mathrm{NiCl}_{2}$, (9) $\mathrm{CuCl}_{2}$, (10) $\mathrm{AgNO}_{3}$, (11) $\mathrm{AlCl}_{3}$, (12) $\mathrm{CaCl}_{2}$, (13) $\mathrm{LiCl}$, (14) $\mathrm{ZnCl}_{2}$, (15) $\mathrm{MnCl}_{2}$, (16) $\mathrm{Hg}\left(\mathrm{NO}_{3}\right)_{2}$, (17) $\mathrm{TiCl}_{3}$. (c) Normalized fluorescence intensity of probe MFC $(10 \mu \mathrm{M})$ in the presence of $20 \mu \mathrm{M}$ of different palladium-containing compound (d) normalized fluorescence responses of probe MFC $(10 \mu \mathrm{M})$ to palladium-containing compound $(20 \mu \mathrm{M})$ with $\mathrm{NaBH}_{4}$ at trace concentration lexcept $\left.\mathrm{Pd}\left(\mathrm{PPh}_{3}\right)_{4}\right]$ in DMSO-PBS buffer $(10 \mathrm{mM}, \mathrm{pH}=7.4), \lambda_{\mathrm{Ex}}=560 \mathrm{~nm}, \lambda_{\mathrm{Em}}=$ $612 \mathrm{~nm}$. (1) $\mathrm{Pd}\left(\mathrm{PPh}_{3}\right)_{4}$, (2) $\mathrm{Pd}\left(\mathrm{PPh}_{3}\right)_{2} \mathrm{Cl}_{2}$, (3) $\left(\mathrm{NH}_{4}\right)_{2} \mathrm{PdCl}_{6}$, (4) $(\mathrm{MeCN})_{2}-$ $\mathrm{PdCl}_{2}$, (5) $\mathrm{PdCl}_{2}$.

\section{Mechanism}

According to previously reported probes with an allyoxy allyoxycarbonyl group for the sensing of $\mathrm{Pd}^{0}$, it is proposed that the trigger moiety of the allyl chloroformate unit is initially conjugated with palladium and ionized to form MFC- $\mathrm{Pd}^{0}$ complex and further dissociates $\pi$-allylpalladium(II) to produce $(E)-4-(2$ (4-cyano-5-(dicyanomethylene)-2,2-dimethyl-2,5-dihydrofuran3-yl)vinyl)phenyl carbonate, then decarboxylates to produce the compound MFO (Scheme 1). ${ }^{38}$ which was further verified by the ${ }^{1} \mathrm{H}$ NMR spectra for the probe MFC and the mixture of the probe MFC with $\mathrm{Pd}\left(\mathrm{PPh}_{3}\right)_{4}$ in deuterated reagents (Fig. 5). The chemical shifts of $\mathrm{Ha}(\mathrm{Hb}), \mathrm{Ha}^{\prime}\left(\mathrm{Hb}^{\prime}\right)$ in compound MFO and MFC are 7.79 (6.89) ppm and 8.02 (7.42) ppm, respectively. When probe MFC was treated with $\mathrm{Pd}\left(\mathrm{PPh}_{3}\right)_{4}$, it was clearly observed that new peaks attributed to $\mathrm{Ha}$ and $\mathrm{Hb}$ was generated. Moreover, HRMS analyses also indicated that the free MFO was produced during the detection process (Fig. S12 in $\mathrm{ESI} \dagger)$.

\section{Cell fluorescence imaging}

Those above findings were encouraging to explore the possibility of using probe MFC for intracellular sensing of $\mathrm{Pd}^{0}$ in living cells, which was conducted using HEK293 cells. The cells were purchased from China Center for Type Culture Collection (Wuhan, China). As shown in Fig. 6c, free probe MFC exhibited almost no fluorescence signal, which was consistent with the above fluorescence studies. Contrastingly, after incubation with $\mathrm{Pd}^{0}$ for $30 \mathrm{~min}$, a strong fluorescence response could be observed (Fig. 6b). The results demonstrated that probe MFC is 


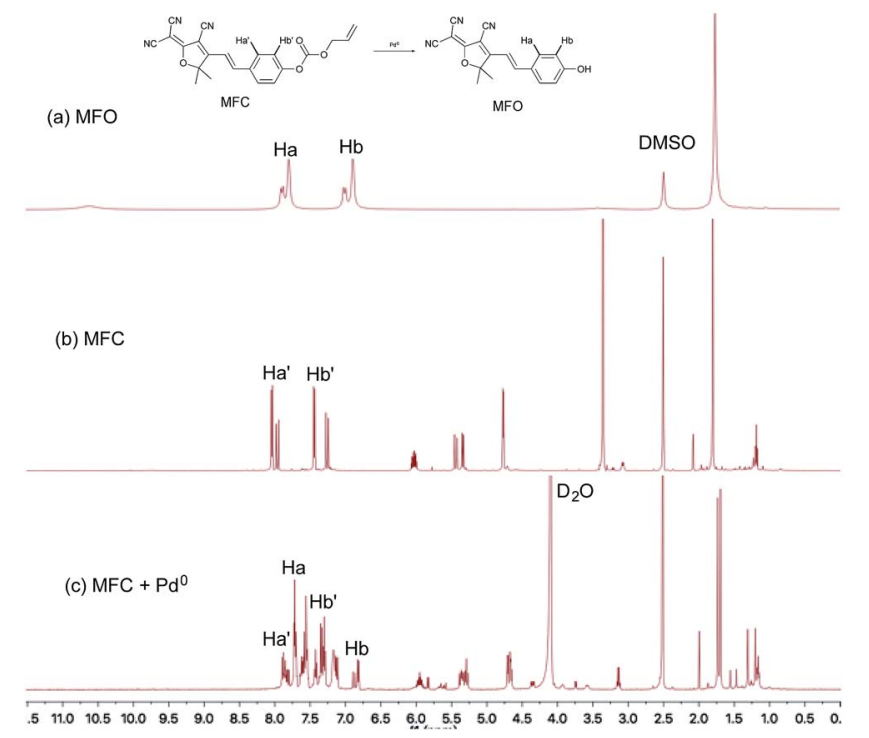

Fig. $5{ }^{1} \mathrm{H}$ NMR spectra of (a) compound MFO in DMSO- $d_{6}$ and (b) probe MFC in DMSO- $d_{6}$ and (c) probe MFC upon addition of 2 equiv. of $\mathrm{Pd}\left(\mathrm{PPh}_{3}\right)_{4}$ in $\mathrm{DMSO}-d_{6}$ and $\mathrm{D}_{2} \mathrm{O}$.

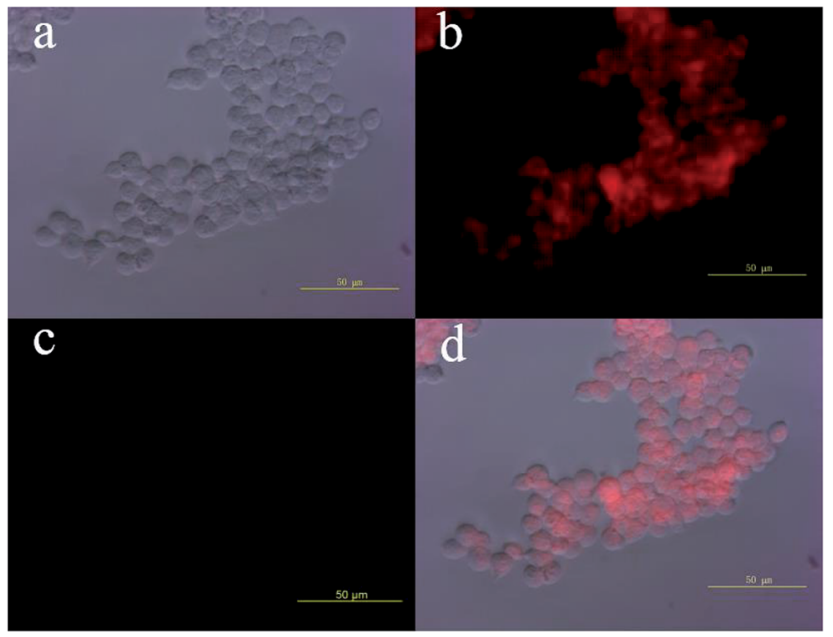

Fig. 6 Fluorescence images of $\mathrm{Pd}^{0}$ detection in HEK293 cells. (a) Brightfield image of cells incubated with $10.0 \mu \mathrm{M}$ probe MFC for $60 \mathrm{~min}$ and then treated with $20 \mu \mathrm{M} \mathrm{Pd}^{0}$ for $30 \mathrm{~min}$ at $37^{\circ} \mathrm{C}$. (b) Fluorescence images of cells in pane (a). (c) Fluorescence image of cells treated with only probe MFC $(10.0 \mu \mathrm{M})$ for $60 \mathrm{~min}$. (d) Overlay image of (a) and (b).

both cell-permeable and capable of detecting palladium in living cells, which contributes it as a versatile tool for the detection of palladium species in living cells and environmental samples.

\section{Conclusions}

In summary, a novel long-wavelength fluorescent probe MFC for discrimination of different palladium species based on $\mathrm{Pd}^{0}$ catalyzed reactions was reported, which exhibited high sensitivity and excellent selectivity towards $\mathrm{Pd}^{0}$ over other competitive metal ions. The excellent selectivity is due to the highly specific $\mathrm{Pd}^{0}$-triggered cleavage process and the long wavelength emission fluorescence should be attributed to the substrate preference and the principle of intramolecular change transfer. Probe MFC responds totally different to the different oxidation states of palladium species, and have short response times and low detection limit towards $\mathrm{Pd}^{0}$ species. This strategy would provide a new opportunity for fluorescent sensing of palladium species with the emission in the red range and high selectivity.

\section{Acknowledgements}

This work was supported by the funding from the National Natural Science Foundation of China (Grant No. 21405043, 21675051, 21375037 and 21205038) and the Hunan Natural Science Foundation (13JJ2022).

\section{Notes and references}

1 G. Zeni and R. C. Larock, Chem. Rev., 2004, 104, 2285-2309. 2 T. W. Lyons and M. S. Sanford, Chem. Rev., 2010, 110, 11471169.

3 R. Jana, T. P. Pathak and M. S. Sigman, Chem. Rev., 2011, 111, 1417-1492.

4 S. MacQuarrie, J. H. Horton, J. Barnes, K. McEleney, H.-P. Loock and C. M. Crudden, Angew. Chem., Int. Ed., 2008, 47, 3279-3282.

5 D.-G. Cho and J. L. Sessler, Chem. Soc. Rev., 2009, 38, 16471662.

6 R. R. Barefoot, TrAC, Trends Anal. Chem., 1999, 18, 702-707.

7 J. Kielhorn, C. Melber, D. Keller and I. Mangelsdorf, Int. J. Hyg. Environ. Health, 2002, 205, 417-432.

8 K. Leopold, M. Maier, S. Weber and M. Schuster, Environ. Pollut., 2008, 156, 341-347.

9 C. D. Spicer, T. Triemer and B. G. Davis, J. Am. Chem. Soc., 2012, 134, 800-803.

10 R. M. Yusop, A. Unciti-Broceta, E. M. V. Johansson, R. M. Sanchez-Martin and M. Bradley, Nat. Chem., 2011, 3, 239-243.

11 T. A. Kokya and K. Farhadi, J. Hazard. Mater., 2009, 169, 726733.

12 K. Van Meel, A. Smekens, M. Behets, P. Kazandjian and R. Van Grieken, Anal. Chem., 2007, 79, 6383-6389.

13 B. Dimitrova, K. Benkhedda, E. Ivanova and F. Adams, J. Anal. At. Spectrom., 2004, 19, 1394-1396.

14 L. Duan, Y. Xu and X. Qian, Chem. Commun., 2008, 47, 63396341.

15 A. P. de Silva, H. Q. N. Gunaratne, T. Gunnlaugsson, A. J. M. Huxley, C. P. McCoy, J. T. Rademacher and T. E. Rice, Chem. Rev., 1997, 97, 1515-1566.

16 H. M. Kim and B. R. Cho, Chem. Rev., 2015, 115, 5014-5055. 17 Y. Yang, Q. Zhao, W. Feng and F. Li, Chem. Rev., 2013, 113, 192-270.

18 J. Zhou and H. Ma, Chem. Sci., 2016, 7, 6309-6315.

19 J. Du, M. Hu, J. Fan and X. Peng, Chem. Soc. Rev., 2012, 41, 4511-4535. 
20 W. Su, B. Gu, X. Hu, X. Duan, Y. Zhang, H. Li and S. Yao, Dyes Pigm., 2017, 137, 293-298.

21 J.-w. Yan, X.-l. Wang, Q.-f. Tan, P.-f. Yao, J.-h. Tan and L. Zhang, Analyst, 2016, 141, 2376-2379.

22 K. Xiang, Y. Liu, C. Li, B. Tian and J. Zhang, RSC Adv., 2015, 5, 52516-52521.

23 J. Qin, X. Li, Z. Chen and F. Feng, Sens. Actuators, B, 2016, 232, 611-618.

24 W. Luo and W. Liu, J. Mater. Chem. B, 2016, 4, 3911-3915.

25 Y. Liu, K. Xiang, M. Guo, B. Tian and J. Zhang, Tetrahedron Lett., 2016, 57, 1451-1455.

26 M. Liu, T. Leng, K. Wang, Y. Shen and C. Wang, J. Photochem. Photobiol., A, 2017, 337, 25-32.

27 Y. Yang, J. Liu, H. Xiao, Z. Zhen and S. Bo, Dyes Pigm., 2017, 139, 239-246.

28 Y. J. Wang, Y. Shi, Z. Wang, Z. Zhu, X. Zhao, H. Nie, J. Qian, A. Qin, J. Z. Sun and B. Z. Tang, Chem.-Eur. J., 2016, 22, 9784-9791.

29 Y.-R. Wang, L. Feng, L. Xu, Y. Li, D.-D. Wang, J. Hou, K. Zhou, Q. Jin, G.-B. Ge, J.-N. Cui and L. Yang, Chem. Commun., 2016, 52, 6064-6067.
30 C. Li, M. Li, Y. Li, Z. Shi, Z.-J. Li, X. Wang, J. Sun, J. Sun, D. Zhang and Z. Cui, J. Mater. Chem. C, 2016, 4, 83928398.

31 H.-R. Kim, R. Kumar, W. Kim, J. H. Lee, M. Suh, A. Sharma, C. H. Kim, C. Kang and J. Seung Kim, Chem. Commun., 2016, 52, 7134-7137.

32 H. Wang, Y. Yang, J. Liu, F. Liu, L. Qiu, X. Liu and Z. Zhen, Mater. Lett., 2015, 161, 674-677.

33 M.-Y. Wu, K. Li, C.-Y. Li, J.-T. Hou and X.-Q. Yu, Chem. Commun., 2014, 50, 183-185.

34 M. K. Lee, J. Williams, R. J. Twieg, J. Rao and W. E. Moerner, Chem. Sci., 2013, 4, 220-225.

35 J. Wu, S. Bo, J. Liu, T. Zhou, H. Xiao, L. Qiu, Z. Zhen and X. Liu, Chem. Commun., 2012, 48, 9637-9639.

36 L. Feng, Z.-M. Liu, L. Xu, X. Lv, J. Ning, J. Hou, G.-B. Ge, J.-N. Cui and L. Yang, Chem. Commun., 2014, 50, 1451914522.

37 D. Villemin and L. Liao, Synth. Commun., 2001, 31, 17711780.

38 W. Luo and W. Liu, Dalton Trans., 2016, 45, 11682-11687. 